\title{
Neutrality and the Dutch Objection Procedure $^{1}$
}

\author{
Marc Wever \\ University of Groningen, The Netherlands \\ marc.wever@rug.nl
}

\author{
A. T. Marseille \\ University of Groningen, The Netherlands \\ a.t.marseille@rug.nl
}

\section{ABSTRACT}

In the Netherlands, if someone disagrees with an administrative order, he is only allowed to seek redress with the administrative courts after he has lodged an objection with the administrative authority responsible for the order. The objection procedure entails that an administrative body reconsiders its own decision. In this contribution we study the preference of objectors concerning the organization of the procedure and to what extent their preference is related to the perceived (lack of) neutrality of the person who conducted their hearing. In particular we focus on the effects of the use of neutral 'outsiders' when conducting hearings. Based on the literature we assumed that the use of outsiders would benefit the experienced impartiality of the person(s) conducting the hearing. The results of two discussed studies however do not support this assumption. The formal status of the persons conducting the hearing is a poor predictor of the extent to which they are perceived as neutral by participants of the procedure.

Keywords: neutrality, dispute resolution procedures, administrative pre-trial procedures, Dutch administrative law, procedural justice.

JEL: $K 410$

\section{Introduction}

In the Netherlands, if someone disagrees with an administrative order, he is only allowed to seek redress with the administrative courts after he has lodged an objection with the administrative authority responsible for the order. The objection procedure entails that an administrative body reconsiders its own decision at the request of an interested party. The administrative body can

1 This article is a revised version of the paper entitled 'Neutrality and the Dutch Objection Procedure, presented at the EGPA Conference, Milano, 30 August- 1 September, 2017. The EGPA contributions are not publicly available. 
choose to keep the decision the way it was or to change or withdraw the disputed decision and, if necessary, take a new one replacing it (Langbroek, Remac and Willemsen, 2014, p. 113-151).

On 29 January 2009, the Dutch newspaper Trouw opened with an article with the headline 'Objecting to municipal decisions pointless'. ${ }^{2}$ The following quote is from the same article: ${ }^{3}$

Just after the mayor of Alkmaar, a municipality north of Amsterdam with 100.000 inhabitants, decided to close most of the windows in the red light (prostitution) area, a 'window operator' decided to object to the decision. Together with his lawyer, he filled an objection. The public hearing that followed was chaired by the mayor himself, while two of his officials also served as commissioner. "Because that is common in Alkmaar," the mayor said.

The objectors' lawyer speaks of an "extremely strange situation". Filling a successful objection against a municipality's decision becomes "very difficult" because nobody can guarantee that the review of the decision is done in a sufficiently independent and objective manner.

According to Professor of Public Administration Michiel de Vries of the Radboud University Nijmegen, "the way Alkmaar does things is absolutely undesirable. Even the slightest appearance of a conflict of interests must be avoided. You cannot decide on an objection against your own decision." Professor Hans Engels calls the Alkmaar model "strange and unbelievable. The municipality must look for the most qualified members to man such a committee. A commission must be independent, so that the citizen knows that his objection is being taken seriously. A hearing can therefore not be chaired by the same person who took the contested decision."

The municipality, through the Mayor's Legal Adviser, states that Alkmaar does not have an independent objection committee. According to the legal advisor, it is "not strange at all that the mayor reviews his own decisions: the very point of the objection procedure is that the decision is reviewed by the administrative body responsible for it and that is the mayor in this case."

This quote shows that what individuals knowledgeable about Dutch administrative law find self-evident, is seen as a highly curious phenomenon by persons who are (somewhat) less well informed about administrative law. How can an objector trust that his objection is considered in a serious and unbiased manner, if the review is done by the very administrative body that made the challenged decision?

Even though it is in practice not very common that the administrative body itself conducts the hearings of objectors, the 'core' of the objection-procedure in the Dutch General Administrative Law Act (GALA) is that, exactly as the Alkmaar mayor's legal advisor stated, administrative authorities review their own decisions. Administrative bodies are free to establish an independent advisory committee, but they can also choose to conduct the hearings

2 https://www.trouw.nl/home/bezwaar-maken-tegen-gemeentebesluit-zinloos- a75d557e/.

3 To reduce the length of the quote, minor changes to the text have been made. 
themselves or to let one or more officials who work under their responsibility conduct the hearings (Wever, 2016).

The percentage of administrative authorities in the Netherlands that make use of an independent committee has been declining steadily over the past few years (Wever, 2016). One of the reasons for this trend is the rise of the 'informal proactive approach model (De Graaf and Marseille, 2012, p. 126-143). This model entails that administrative authorities try to contact objectors as soon as possible after an objection is filled, to see whether agreement about the settlement of the dispute can be reached. ${ }^{4}$ It is thought that an independent committee is less capable to perform this task than one or two skilled civil servants are, because these officials can more easily explore the possibilities for finding a solution to the problem that led to the objection (Allewijn, 2015, and Herweijer and Lunsing, 2011). However, not all administrative authorities are getting rid of their independent objection committee. While some administrative authorities switched from an objection procedure with a prominent role for independent outsiders, to an objection procedure which is dominated by officials, other administrative authorities are in fact considering the exact opposite, meaning they are thinking about establishing an external objection committee (Marseille, 2016, p. 79-94).

One of the questions this contradictory development raises is how important the objectors themselves find the way in which the hearing is organized. Do they have a preference for a certain type of procedure and if so, how can this preference be explained? This question is not only relevant for the Dutch objection procedure, but for any country with administrative pretrail and complaint procedures. Two studies carried out in 2016, one with the municipality of Groningen, the other with the municipality of Tilburg (conducted by the authors themselves), shine a light on this question (Meijer and Latenstein van Voorst, 2017; Marseille, De Waard and Wever, 2017). Before discussing the findings of these studies (in paragraphs 4 and 5) we briefly outline the legislator's ideas about the importance of neutrality (paragraph 2), and discuss relevant literature about the relationship between the way in which the objection procedure is organized and how it is appreciated by objectors, especially concerning neutrality and objectivity (paragraph 3). We end with a brief conclusion (paragraph 6).

\section{The Objection Procedure: Neutrality Guaranteed?}

The objection procedure in the Netherlands entails that an administrative body reconsiders its own decision. However, the procedure that results in the decision upon the objection can be 'outsourced'. The options available to the administrative authority are outlined in articles 7:5 and 7:13 of the General Administrative Law Act (GALA). It is stated there that the administrative

4 See for more about this model: Ministerie van Binnenlandse zaken en Koninkrijksrelaties, Professioneel behandelen van bezwaarschriften, http://prettigcontactmetdeoverheid.nl/ sites/default/files/documenten/Handleiding\%20Professioneel\%20behandelen\%20van\%20 bezwaarschriften_0.pdf Handreiking. 
authority can conduct the hearing of the objectioner itself, ${ }^{5}$ that it can enable one or more independent outsiders to conduct the hearing, or that it can task one or more of its officials to conduct the hearing. In the case that a single official conduct the hearing, this official may not have been involved in the preparation of the contested decision. And, if the hearing is conducted by two or more officials, the majority of those officials, including the person who is in charge of the hearing, may not have been involved in the preparation of the contested decision.

The issue of neutrality in (administrative) dispute resolution procedures is not unique to the Netherlands. For instance, both France and Germany have somewhat similar pre-trial procedures where neutrality is also a potential issue. For example, France has a procedure called recours administrative prealable. Just like in the Dutch objection procedure, the French procedure entails that the objection is addressed to the administrative authority responsible for the contested decision. In France there are no general rules as to the organization of the procedure. If the administrative authority finds it necessary or if the law requires it to do so, objectors are given the opportunity to be heard prior to making a decision. Concerning the issue of neutrality, it is interesting to note that French law prescribes the use of independent commissions in some cases, while in other types of cases administrative authorities are allowed to handle objections by themselves (Langbroek, Buijze and Remac, 2012, p. 54).

Germany has the so-called Widerspruch procedure. Just like the French and Dutch objection procedures, objections are handled by the administrative authority that was responsible for the disputed decision. Section 28 VwVFG specifies the cases in which objectors are to be given the right to be heard before a decision is reached. In the Widerspruch procedure, the issue of neutrality is most visible in the way the decisionmaking is organized. If the administrative authority agrees with the objector that the initial decision is wrong, the administrative authority can withdraw or change the disputed decision itself. However, if it does not agree with the objector and wants to maintain its initial decision, the administrative authority must send the objection to a Widerspruchbehörde, in most cases a superior administrative authority, which then decides upon the objection. When a hearing takes place (section $71 \mathrm{VwCO}$ ), the neutrality is guaranteed because not the administrative authority that took the decision conducts the hearing, but the superior administrative authority (Hufen, 2011, p. 107).

The parliamentary history of the Dutch GALA shows that the rules that govern the hearings by officials and the possibility of establishing an external objection committee were meant to contribute to the objective reassessment of contested decisions. However, paradoxically, it is also stated that the legislator would prefer it if the hearing would be conducted by the administrative authority itself. Only because it would impossible for administrative authorities that deal with a large number of objections to

5 Article 7:5-1 GALA states that if the administrative authority consists of multiple persons, one of its members can conduct the hearings. 
conduct the hearings themselves, does the GALA offer the opportunity to enlist the help of others. It is stated in the explanatory memorandum that it is "desirable that those involved in the preparation of the contested decision do not determine the course of hearing" but also that they "of course may be present, which will often also benefit the exchange of views at the hearing" (Daalder and De Groot, 1993, p. 340). In what capacity the administrative authority should be present, the explanatory memorandum does not state, but given the text of article 7:5 GALA this could be in the role of 'defendant' (to explain the position of the administrative authority), but also as a member of the hearing committee.

Neither in the explanatory memorandum to article 7:5 GALA, nor in the explanatory memorandum to article 7:13 GALA, much is said about the importance of objectiveness and independence when handling objections. But the legislator does implicitly pay attention to this. This is shown by the fact that the officials responsible for the contested decision can only have a limited role at hearings, and in the fact that the GALA provides for the possibility to establish an independent hearing and advisory committee. However, the considerations in the explanatory memorandum about the way hearings are to be conducted are mainly focused on the question what type of procedure offers the best opportunities for finding agreement between the objector and administrative authority. Objectiveness and independence receive far less attention in that respect. The legislator apparently assumes that neutrality does not require the use of outsiders, but can also be guaranteed when the administrative authority chooses to make use of its own officials.

\section{Literature: How Important is Neutrality?}

Why do we care about neutrality? The function of procedures of decisionmaking and dispute resolution is that the objectives pursued by substantive law are achieved as much as possible. British scholar Galligan (1997) states:

'Without procedures, law and legal institutions would fail in their purposes. And since law is both necessary and desirable in achieving social goals, procedures are also necessary and must be seen as equal partners in that enterprise. For whatever the context, whether the judicial trial, the administrative decision, or any other form of legal process, procedures are necessary to ensure that the issue is channeled to its right conclusion.'

In Galligan's view, the purpose of procedures is to ensure that a correct outcome is achieved in any given case. Galligan sees neutrality an important aspect of good procedures, because neutrality is necessary to ensure that the right outcomes are reached and thus that people are treated fairly. Though not all perspectives share this instrumental view on procedures, most theoretical perspectives view the neutrality of the officials involved in the procedure as one of the vital the characteristics of good procedures. . Another notable author, Bayles, considers neutrality as one of five principles of good dispute resolution procedures from the perspective of rational outsiders, together 
with the right to be heard, the right to appeal, equal application of procedural rules and outcomes in accordance with the law (Bayles, 1990).

One of the most influential perspectives on good procedures of the last decades - at least in the Netherlands - has been the body of literature on procedural justice. Procedural justice is, as the name implies, concerned with the factors that cause people to view dispute resolution procedures (and rules) as just. According to this perspective neutrality is one of the core explanatory factors of why people view procedures as just, together with other criteria such as the lack of bias, honesty, an effort to be fair, politeness, and respect for rights (Tyler, 1990). In this view, procedures that are viewed as fair lead to outcomes being viewed as fair, and more often accepted as correct by parties.

By contrast, in the Dutch literature about the objection procedure the subject of neutrality receives relatively little attention. The question of whether or not it would be preferable to have hearings conducted by an external committee is frequently discussed, but the arguments for and against the involvement of independent outsiders revolve mostly around the problem solving capacity of the objection procedure, and hardly ever on the importance of neutrality.

A first example of this focus on problem solving is provided by an extensive study of the objection procedure by Breeuwsma et al. This study was conducted more than 35 years ago, even before the introduction of the GALA. The researchers prefer it when administrative authorities establish an external committee, but not because of the independent position of such a commission. They prefer this because the inclusion of outsiders in the objection procedure would provide the best opportunities for the full reconsideration of the contested decision, and would furthermore be conducive to the uniformity, efficiency, filtering and problem solving ability of the objection procedure (Breeuwsma, 1984, p. 347).

The formal GALA-evaluations that were held in the first decade after the law was introduced also do not place the objective and neutral appraisal of objections at the center of attention (Polak, 1996, p. 43-44). In the 'Report of the Committee on Evaluation of General Law of Administrative Law' (known as the Polak Commission report) from 1996 it is recommended to, where possible, create a personal separation between the people tasked with handling objections and the persons involved in the initial decision making process to promote an unbiased review. However, the Polak-committee does not favor or oppose the involvement of outsiders in the objection procedure. ${ }^{6}$

In the response of the Dutch government following the first evaluation of the GALA, it is mentioned that the use of an external committee is only favored when significant interest are at stake or when complex legal issues are to be considered. The independent position of an external committee is not mentioned as an argument in favor of using one in those cases.

6 Parliamentary Papers II, 1997/98, 25600 VI, nr. 46, p. 28. 
In the context of the second evaluation of the GALA, Aalders et al. (2001) cite various requirements that the persons that are involved with the hearings of objectors should (preferably) meet. None of them should for instance have been involved in the preparation of the contested decision, they should be sufficiently unfounded with regard to the contested decision and have a certain distance to the administrative authority, and they should be capable to review both the legality and effectiveness of the disputed order. However, the researchers do not express a preference for dealing with objections using an external committee (Aalders et al., 2001, p. 122).

What do objectors want?

Examination of the Dutch literature on the factors that affect the perceived objectivity of the people who conduct objection hearings, shows that it is not easy to determine the importance objectors attach to the way hearings are organized. For instance, Van Montfort \& Tromp (2000) compared the satisfaction of objectors who had faced an external committee with the satisfaction of objectors who were heard by civil servants (Van Montfort and Tromp, 2000, p. 344). They expected that objectors would be more satisfied with a procedure where an external element was more strongly represented, as is the case when an external committee conducts the hearing. However, they did not find any correlation between the composition of the hearing committee and the satisfaction of the objectors. It was striking that objectors often thought that they had been heard by an internal objections committee (e.g. civil servants) while in fact they were heard by an external objection committee. The authors state that this may provide an explanation for the lack of a difference in appreciation (Van Montfort and Tromp, 2000, p. 355).

De Waard et al. (2011) encountered the same confusion among objectors. Their research also shows that many objectors have the wrong idea about who conducted their hearing. For example, objectors at the Social Insurance Bank thought that they had been heard by an independent committee, while hearings there are always conducted by civil servants (De Waard et al., 2011, p. 76).

The research by De Ward et al. does not provide an answer to the question whether or not the fact that a hearing is conducted by an external committee influences objectors' appreciation of the hearing. However, the study does show that objectors find the neutrality of the people who conduct the hearing very important. And, it also shows that their judgment about the neutrality of the people who conducted the hearing is quite negative: $60 \%$ of the respondents doubted the neutrality of the people who conducted their hearing (De Waard, 2011, p. 73).

The objectors' judgement of the neutrality impacted their general appreciation of the objection procedure more than for instance the perceived reliability of the persons conducting the hearing, or whether or not they thought that they had been able to sufficiently present their point of view (De Waard e.a., 2011, p. 96). This could be a reason to assume that objectors who were heard by an 
independent committee are more satisfied with the proceedings in general than objectors who had been heard by officials. However, the study does not show any significant differences between the two categories of objectors (De Waard et al., 2011, p. 123, and Marseille, 2016, p. 91).

All in all, Dutch studies into the functioning of the objection procedure did not result in a clear preference for the use of an external committee. The results of research into the assessment of objectors of the objection procedure are paradoxical: objectors strongly emphasize the value of neutrality, but at the same time they are rarely aware of the 'status' of the people who conducted their hearing.

In the following two paragraphs we discuss recent research which provides insight into the state of objection treatment in general and into the (relative) importance of the perceived neutrality and objectiveness objection treatment in particular. We start by discussing the results of a very recent study in Tilburg in which both authors were involved.

\section{Tilburg}

\subsection{Introduction}

In Tilburg, a municipality with more than 200.000 inhabitants in the south of the Netherlands, objections can fall into two categories: 'social' (concerning social security legislation and policy) and 'other' (all other subjects, for instance building permits, subsidies, administrative fines, etc.). With objections in the first category, a very limited role is played by independent outsiders. The hearings themselves are conducted by a single civil servant. At the hearing, the administrative authority is not represented in the role of 'defendant'. After the hearing the civil servant writes an advice to the administrative authority as to the decision he or she thinks should be made. In some cases this advice is reviewed by a panel that consists of three outsiders. ${ }^{7}$

In the procedure concerning the 'other' category of objections no outsiders are involved at all. ${ }^{8}$ Objectors are heard by a three-person committee of which all three members work for the municipality. Two members (the chairman and the secretary) work at the Legal Affairs Department, the third member works at the department where the contested decision was prepared. At the hearing, the administrative authority is not represented in the role of 'defendant'. After the hearing is conducted the committee writes an opinion about which decision the administrative authority should adopt.

7 After the hearing the civil servants draft a concept decision upon the objections. These concepts are then discussed by an advisory committee manned by three independent outsiders. The committee decides - based on all available information - if the concept needs to be changed or not before it is presented to the Mayor and Municipal Executive order. The committee usually discusses about 20 to 25 cases per meeting. The meeting itself usually takes half a day.

8 The 'other' cases are all cases which do not concern the social matters. 
In response to questions in the city council about the (lack of) independence in the objection procedure, the Mayor and Municipal Executive ordered a study into the objection procedure in the second half of 2016. In the course of the study the researchers witnessed over 100 hearings and interviewed objectors, their agents, the civil servants involved in the objection procedure, councilors and the Mayor. The perceived neutrality of the people that conduct the hearings was an important element of the study, although it was impossible to compare 'internal' and 'external' proceedings, simply due to the fact that Tilburg has not established an external advisory committee.

\subsection{Findings: the Hearing}

It is common practice that the person who conducts or chairs the hearing tells objectors what his position - and those of his fellow committee members - is. In Tilburg it is important that parties know that they are not being heard by independent outsiders but by officials of the municipality. To what extent is this made sufficiently clear, according to objectors? This is shown in Figure 1.

Figure 1. Did the person conducting the hearing tell you that he works for the municipality? ${ }^{9}$

\begin{tabular}{|r|c|c|c|c|c|}
\hline Social \\
Other
\end{tabular}

The figure shows that objectors are not always told what the status of the people who conduct the hearings is. However, a large majority of objectors who say they have not been told this, do state that they were aware of the status of the people conducting the hearings. The difference between 'social' and 'other' cases is remarkable, but also understandable. In a situation where the hearing is conducted by three people, it is more natural to start the hearing with an introduction of the participants compared to the situation where the hearing is conducted by a single civil servant.

\subsection{Objectors About the Procedure}

How satisfied are the objectors with the way the hearings are conducted in Tilburg? Figure 2 shows this for eight aspects of the hearing. In figure 2 we compare our findings between 'social' and 'other' objections.

9 All graphs presented in this paragraphs are original renditions of our raw data. The category 'I don't remember' has been left out (18\% of the respondents). 
Figure 2. Satisfaction with the hearing

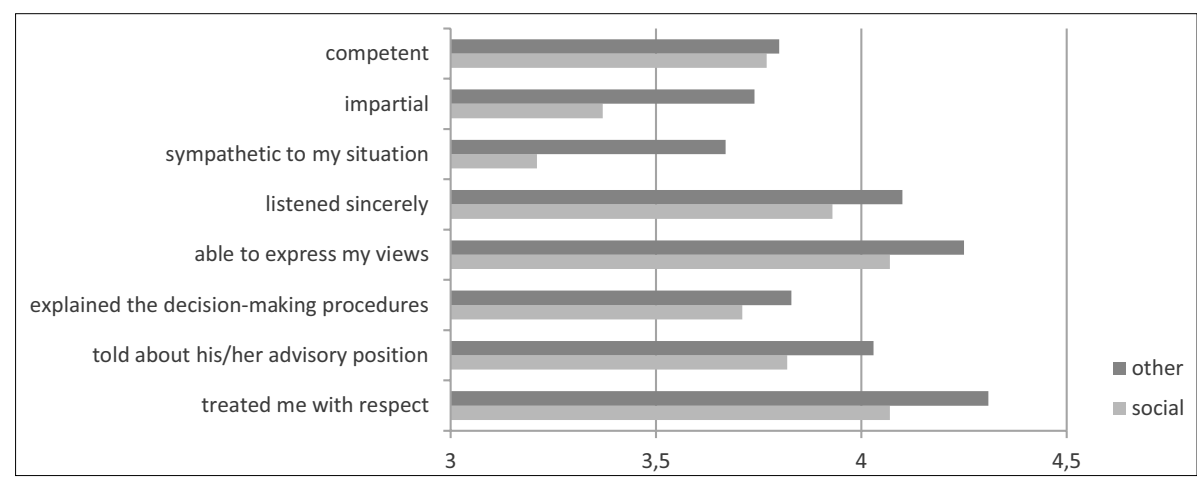

The figure shows the reaction of objectors to eight statements. The respondents were able to choose between five answers, ranging from 'disagree completely' (1) to 'totally agree' (5). To accentuate the differences between the scores, only the range between the lowest and highest rated values has been shown here (from 3 to 5 ).

When we look at the results it is striking, first of all, that none of the average ratings are below the value of 3 . A second result worth mentioning is that objectors in the 'other' category are more satisfied than objectors in the 'social' category. This is true for all 8 statements, although the difference between the two categories of objectors is only statistically significant for two of the propositions: "the person conducting the hearing was sympathetic to my situation" and the second being: "The person conducting the hearing was impartial." Both of these statements were also rated lower than the other aspects of the hearing.

When we look at how the objectors assessed the impartiality of the officials that conducted the hearing, we see that although this aspect is not rated particularly highly, the rating also does not differ significantly from the other examined aspects. It is however remarkable that the score on 'impartiality' in social affairs is lower than is the case in objections in the 'other' category. We shall discuss this result in more detail later on in this contribution.

Based on the answers to the eight statements we were able to measure the procedural justice experienced by objectors. Objectors in 'other' cases scored - on a scale of 1 to 5 - a 4.00 on experienced procedural justice, objectors in social affairs a 3.82. The difference between both categories of objectors is not significant.

We also asked objectors what they thought was the most positive and the most negative aspect of the hearing. Positive comments were made about the atmosphere ("the civil servant was sympathetic to my situation and we had a calm conversation") and the possibility to voice their opinions ("they listened well"). Negative comments were made about the more substantive aspects of the dispute ("they did not look at other possible options"), and a 
perceived lack of respect ("it bothered me that we did not shake hands after the hearing was over") and uncertainty about the procedure following the hearing.

The fact that the hearing was conducted by officials of the municipality and not by independent outsiders was not mentioned by any of the respondents as a negative (or positive) aspect. It is therefore not apparent that objectors experienced a lack of independence or neutrality on the part of the officials that conducted the hearing.

However, the fact that one of the members of the objection committee was an official from the department where the contested decision was prepared did attract a great deal of criticism ("the official responsible for the decision should not be a part of the commission" and: "the fact that the an official from the department responsible for the contested decision is a member of the committee suggests the risk of prejudice"). On this basis, it could be expected that the experienced impartiality in hearings in 'social' objections (where the official from the department responsible for the contested decision is not present) would be rated higher than the impartiality in the hearing in 'other' objections. However, as we have seen, it is the exactly the other way around.

We also asked respondents if they would have preferred it if their objection would have been handled using an external committee. Figures $3 a$ and $3 b$ show the responses to this question.

Figure 3a. Preference (objectors 'other')

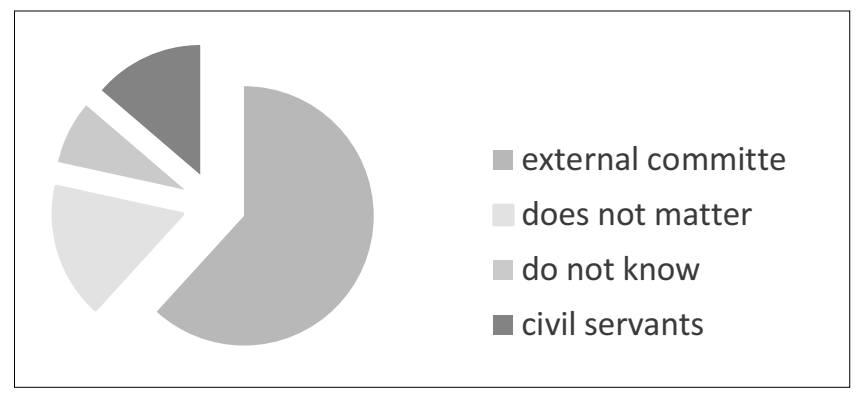

Figure 3b. Preference (objectors 'social')

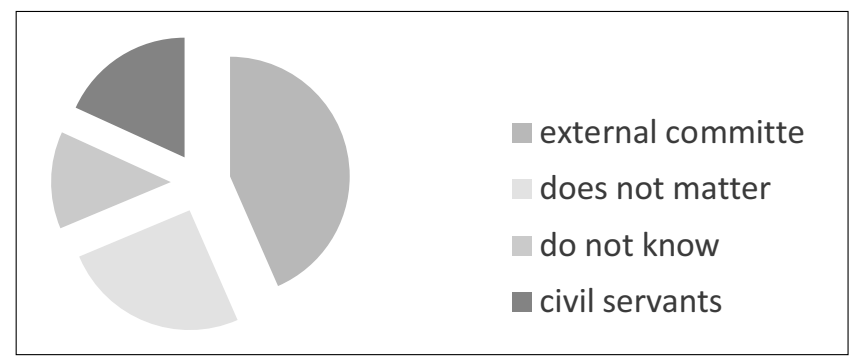


Both figures show that a large majority of objectors would prefer the use of an external committee. The differences between the two categories of objections are striking. In the category 'other', objectors are much more pronounced in their views and have a stronger preference for an external committee than objectors in 'social' objections.

The objectors were also asked to explain their preference. Proponents of an external objection committee in the 'other' category preferred such a committee because they believe this would lead to a more independent, impartial, and objective review of the contested decision. ${ }^{10}$ But it also appears that the objector's preference for an external committee is not unconditional. There are also objectors who note that despite their preference for an external committee, they are satisfied with the way their objection was handled by the civil servant(s) ("the chairman of the committee seemed impartial, I did not have any negative experiences this time"). Other objectors are only in favor of the establishment of an external committee if certain other standards are also maintained ("the committee must consist of experts", and "independence seems better, but such an external commission may be less well-informed than civil servants"). It was also mentioned that the distinction between an external committee and the current procedure in which the hearing is conducted by civil servants, is not as absolute as it may appear ("an external committee does not always mean that there are no conflicts of interest").

Objectors in 'social' cases who preferred an external advisory committee, also felt that the use of an external committee would increase the chances of a neutral, impartial, objective review of the contested order. ${ }^{11}$ It is remarkable that expertise is also mentioned as an argument in favor of hearings by an external committee ("someone specializing in court proceedings could be better" and "they are more able to look at the person"). The preference of objectors in 'social' cases is also nuanced ("I would prefer an outsider, but outsiders can also be partial") or dependent on additional qualifications ("the outsider must be an expert: and knowledgeable about the law, for instance someone who has worked with the government or as a social lawyer").

There are also objectors who oppose the adoption of an external committee. When asked about their preference almost all of them mention the insider knowledge of civil servants as the main reason ("he made the decision, so he knows the facts", "he is familiar with the way things work in Tilburg", "he knows the ins and outs of the case and the way things work").

Which factors influenced the preference of objectors for an external or internal hearing? We take a look at the connection between respondents' preference and their experienced procedural justice. ${ }^{12}$ It appears that the group of objectors who preferred it if the hearings are conducted by an external committee had experienced lower levels of procedural justice

1018 out of the 23 answers to the open questions mentioned these arguments.

1113 out of 20 answers.

12 We compared objectors who preferred an external committee to those who preferred civil servants, those who didn't care and those who didn't know. 
compared to the group of objectors that preferred it if the hearings are conducted by civil servants. The difference is statistically significant.

If we make a distinction between objectors in 'other' and 'social' cases, we see that objectors in the 'social' category that experienced lower levels of procedural justice tend to prefer an external procedure. ${ }^{13}$ For objectors in the 'other' category, such a correlation was not found.

This suggests that the preference of objectors in the 'social' category was primarily influenced by their own experience and satisfaction. On the other hand, objectors in 'other' cases seem to base their preference less on their own experience and satisfaction and more on their opinions about the way the objection procedure should be organized in general.

\subsection{Legal Representatives About the Procedure}

At almost half of the attended hearings the objector was assisted by a (professional) legal representative such as a lawyer or legal advisor. We spoke with 29 of them. ${ }^{14}$ With six lawyers we discussed their views more fully. Lawyers who mainly deal with environmental issues have a strong preference for an independent committee or, at the very least, for a committee with an independent chairman. One such lawyer stated:

"I cannot explain to my clients that there is no independent advisory committee. They do not understand that officials of the municipality advise the municipality. They are also often annoyed by the fact that the very official that upheld the initial decision in the objection procedure, is also the representative of the municipality in the procedure with the administrative courts."

Their main concern with the way the objection procedure is organized in Tilburg, is that a civil servant from the department that prepared the decision official - often the same person who was de facto responsible for the primary decision - is also a member of the hearing committee. This gives objectors the impression that they are being heard by persons who are prejudiced. In addition, they think that the members of the committee have already discussed and determined their position before the hearing has even taken place. Furthermore, they find the contribution of the department official to the discussion unclear, because more often than not that official does not actually says anything during the hearing.

The lawyers with whom we spoke about 'social' cases did not have the impression that the officials who conduct the hearings are prejudiced. They are however critical of the way the civil servants perform their task. A lawyer compares Tilburg and the UWV (EIA, Employee Insurance Agency), an autonomous administrative agency which handles objections in a very similar manner, namely by letting a single civil servant conduct the hearing):

13 Objectors who expected an outcome in their favor preferred civil servants slightly more often. However, the difference is not statistically significant.

14 In 'social' cases: 21 out of 43 hearings we witnessed; in 'other' cases: 31 out of 71 hearings we witnessed. 
"The people conducting the hearings in Tilburg are always very passive. Sometimes you can tell that they do not know the enough about the case. So then the hearing becomes a formality. That's hardly ever the case with the UWV."

This lawyer notes that she hears more complaints about the impartiality of the civil servants conducting the hearing at the municipality of Tilburg than about UWV even though their objection procedures are organized in the same way. She attributes that to the difference in quality between those two government agencies. She says:

\begin{abstract}
"You do not necessarily have to have an independent commission to make sure people feel adequately heard. You need to know the case properly, ask relevant questions, think about the case, and ask yourself: can we handle this matter differently? That is much more important than whether there's officially an external committee or not."
\end{abstract}

\title{
4.5 Conclusion
}

Do objectors to decisions of the municipality of Tilburg prefer a more internal or external objection procedure and if so, what determines their preference? An interesting finding of the study is that when objectors are asked about their preference, a large majority claim to prefer an external committee. Objectors expect that the involvement of outsiders will provide better chances for a more neutral, impartial and objective review of the contested decision.

However, their preference is hardly supported by their assessment of various aspects of the hearing that they actually experienced. Objectors are not significantly more (dis)satisfied with the impartiality of civil servants conducting the hearing than about other aspects of the hearing. And, even when they are asked about the aspect of the procedure they are most critical, they hardly ever mentioned the fact that the hearings are conducted by officials who work for the municipality. The only aspect of the way the procedure is organized in Tilburg that caused much criticism, was the role of the official who was directly involved in the preparation of the disputed decision. Furthermore, the study provides support for the assumption that a preference for internal or external hearing is related to the perceived quality of objection procedure. When objectors are less satisfied with the quality of internal objection treatment, they are more likely to prefer the alternative.

\section{Groningen}

In Groningen, a municipality with more than 200.000 inhabitants in the north of the Netherlands, objections can fall into two categories: 'social' and 'spatial'. Social cases concern matters like social security, while spatial cases concern the physical environment (building permits and the like).

Groningen uses both an external objection advisory committee and civil servants to handle objections (Meijer and Latenstein van Voorst, 2017, p. 36). The external objection committee consists of three members. Two of them, including the chairman, are not employed by the municipality. The 
third member, the secretary, is a legal advisor at the 'Shared Service Center Legal' of the municipality. In the social domain, the external committee is only used in youth, fraud and enforcement cases, as well as other matters if they are particularly complex. This means that in 'social' cases about $80 \%$ of all objections the hearings are conducted by civil servants.

With 'spatial' objections, cases are assigned to the external committee if they have a significant 'public or administrative risk profile'. This is deemed the case when three or more interested parties have filled an objection against a particular decision. In spatial cases only about $20 \%$ of the objectors are heard by civil servants (Meijer and Latenstein van Voorst, 2017, p. 14). If that is the case, the hearings are conducted by two officials, one of whom is in charge of the hearing and the other fulfills the role of secretary.

A notable difference between the way hearings are conducted in 'social' and 'spatial' cases, concerns the presence of a representative of the department which was responsible for the disputed decision. In 'spatial' cases a representative of the department responsible for the decision is invited to the hearing. With objections related to social cases, this is not the case. The reason for this is that the legal department feels it has more understanding of the content of decisions in the social domain than is the case with decisions in the 'spatial' domain (Meijer and Latenstein van Voorst, 2017, p. 14).

In 2016, a study into the satisfaction of objectors and their legal representatives with the objection procedure was conducted. Objectors were asked to participate in a web survey about their experiences (Meijer and Latenstein van Voorst, 2017, p. 8-9). A total of 192 objectors were approached, 92 of whom were heard by civil servants and 100 by the external committee. 55 objectors completed the survey, 31 of which were heard by civil servants and 24 by an external committee (Meijer and Latenstein van Voorst, 2017, p. 48). With some of the respondents the researchers spoke more in detail about their experiences. They were asked to elaborate on the answers they gave in the web-survey and about their views on the objection procedure in general. In addition, interviews with legal advisers and civil servants were conducted with a similar set-up.

The surveyed objectors were noticeably more negative about the objection procedure than their counterparts in Tilburg. They rate the objection procedure in Groningen a 4.4 out of 10. A quarter of the respondents even rated the procedure a 1 out of 10 (Meijer and Latenstein van Voorst, 2017, p. 51). When asked to explain their rating, respondents stated that they felt that the outcome of the procedure was already decided before the hearing even took place, that the municipality did not take into account the arguments that they had put forward and that the municipality did not review the contested decision fairly.

How can this poor evaluation be explained? We are particularly interested in the question if there is a correlation between the manner the objection was dealt with and the rating that was given by objectors. However, that does not 
appear to be the case. Objectors that experienced the external committee were equally dissatisfied with the procedure as a whole as the objectors that were heard by civil servants. There is however a clear difference between objectors who had won the procedure and those who had lost. The first group rates the procedure with a 6.5 , the second with a 3.3. ${ }^{15}$

When asked about their appreciation of the hearing they experienced, respondents were somewhat more positive. The hearing itself received a passing grade, although barely (objectors who were heard by civil servants rated the hearing a 5.8 out of 10 ; objectors who were heard by the external commission rated the hearing a 5.6).

When asked specifically about several aspects of the hearing they experienced a more nuanced image appears. Figure 4 shows the extent to which objectors agree with five statements about the hearing (Meijer and Latenstein van Voorst, 2017, p. 55-67). ${ }^{16}$

Figure 4. Satisfaction with the hearing

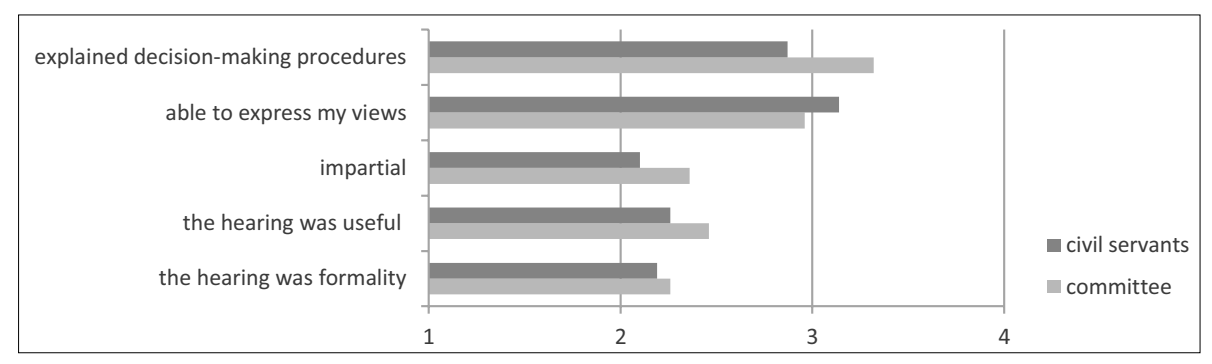

The figure shows, first of all, that the views of objectors who were heard by civil servants and those who were heard by an external committee did not differ to a great extent. ${ }^{17}$ In addition, it appears that there is a clear difference between the objectors' assessment of the factual course of events during the hearing (the first two statements) and their appreciation of the hearing (the last three statements). ${ }^{18}$ The responses to the first two statements are clearly more positive than those to the last three statements.

For our current purposes we are particularly interested the responses to the statement: 'The people conducting the hearing were impartial.' The responses of objectors heard by civil servants to that statement barely differed from those of objectors heard by an external committee. While it is true the rating of the latter group is slightly higher (while perhaps more fitting: slightly less low), the difference is not statistically significant and does not differ from the overall picture.

15 This concerns the group heard by civil servants. The difference is not significant $(p<.05)$. The same goes for the group heard by the external committee.

161 means: strongly disagree, 4 means: strongly agree.

17 The researchers do not say if the correlations are significant. However due to the small number of observations, we do not expect them to be.

18 The last statement was formulated differently, we recoded the answers accordingly. 
In addition to the web survey the researchers also spoke with five legal counselors. They too are more positive about the hearing conducted by civil servants. However, the preference for hearings by civil servants is not related to an experienced lack of impartiality of the people conducting the hearings. Legal councilors like the atmosphere better and they find that more time per hearing is taken. They did not seem to have a fundamental preference for the use of outsiders. The way the person who conducts the hearing performs his tasks is more important. Most importantly, they mention that the hearing should never be just about passively listening to what the objector has to say.

What insight does the study of the objection procedure of Groningen provide us into the preference of objectors? The study shows that objectors in Groningen are in general rather negative about the objection procedure. The hearing itself gets only a slightly better grades. For the overall satisfaction of objectors it did not matter if the hearing was conducted by civil servants or by the external objection committee. The same goes for the experienced impartiality of person(s) conducting the hearing. The differences between the two categories of objectors were minor. A possible explanation for this finding could be that people base their judgement more on the performance of the person conducting the hearing than on their 'formal' status as outsider or insider.

\section{Conclusion}

In this contribution we discussed two empirical studies into the functioning of the Dutch GALA objection procedure of two large municipalities in the Netherlands. In particular, we were interested in the preference of objectors concerning the organization of the procedure and if, and how, their preference was related to the perceived (lack of) neutrality of the person who conducted their hearing.

Based on the literature we assumed that the use of outsiders would benefit the experienced impartiality of the person(s) conducting the hearing. The results of two discussed studies however do not support this assumption. Neither objectors in Tilburg nor those in Groningen perceived a lack of neutrality on the part of the civil servants conducting the hearings. The study in Groningen showed no significant differences between objectors who were heard by an external committee and those who were heard by civil servants working under the responsibility of the administrative authority that took the contested decision.

This does not take away from the fact that, when given a choice, most objectors would prefer the involvement of outsiders. The study focusing on Tilburg showed that even though most objectors did not experience a lack of neutrality, a large majority of them would prefer an external objection committee because they believe it would lead to a more independent, impartial and objective review of the contested decision. How can we explain this? Two possible explanations where found. The first explanation we found 
was that the objectors, who experienced lower levels of procedural justice, were more likely to prefer the alternative (being: an external committee). The second explanation was that objectors felt that the use of outsiders would be more appropriate in general, considering the nature of the objection procedure itself.

The implications of our findings could be relevant for countries who have similarly organized administrative pre-trail procedures to the Dutch objection procedure. Specifically, that the use of outsiders does not automatically result in increased experienced impartiality. The status of the persons conducting the hearing is just one of the factors that influence objectors' assessment of the quality of the hearing. More important than their formal 'status', is the actual way the person conducting the hearing performs his or her task. The status of the person conducting the hearing does become more salient for objectors when they are less pleased with the way the civil servant performed during the hearing and - on a more principal note - if the administrative authority itself has a significant interest in a certain outcome of the objection procedure. Authorities would be advised to take these findings into account when designing pre-trial procedures.

Marc Wever and A. T. Marseille work for the department of Constitutional Law, Administrative Law and Public Administration at the University of Groningen. 


\section{References:}

Aalders, M.V.C. et.al. (2001). De burger en de Awb: ervaringen van repeat players met Awb-procedures. Den Haag: BJu 2001.

Allewijn, D. (2015). De bezwaaradviescommissie: ombouwen of afschaffen. TvC (2), 14-18.

Bayles, M.D. (1990). Procedural Justice: Allocating to individuals.Dordrecht: Kluwer Academic Publishers.

Breeuwsma, C.M. et al. (1984). Beeld van de Arob-bezwaarschriftenprocedure. Groningen: Kluwer.

De Waard, B.W.N. et al. (2011). Ervaringen met bezwaar. Onderzoek naar de ervaringen van burgers met de bezwaarschriftprocedure uit de Algemene wet bestuursrecht. Den Haag: BJu.

Daalder, E.J. and G.R.J. de Groot. (1993). Parlementaire Geschiedenis van de Algemene wet bestuursrecht. Alphen aan den Rijn: Samsom H.D. Tjeenk Willink.

Galligan, D.J. (1997). Due Process and Fair Procedures: A Study of Administrative Procedures. Oxford: Oxford University Press.

Herweijer, M. and J.L. Lunsing. (2011). Hoe beleven burgers de bezwaarprocedure. Den Haag: Ministerie van Binnenlandse Zaken en Koninkrijksrelaties.

https://www.trouw.nl/home/bezwar-maken-tegen-gemeentebesluit-zinloosa75d557e/. Retrieved 6 december 2017.

Hufen, Friedhelm (2011). Verwaltungsprozessrecht. München: Verlag C.H. Beck.

Langbroek, P., Milan Remac and Paulien Willemsen (2014),'The Dutch System of Dispute Resolution in Administrative Law', in: Dacian C. Dragos \& Bogdana Neamtu (eds), Alternative Dispute Resolution in European Administrative Law, Springer, p. 113-151.

Langbroek, P., A. Buijze and M. Remac. (2012). Designing administrative pre-trial proceedings. Utrecht: Eleven Publishing.

Marseille, A.T. and K.J. de Graaf. (2012). Criteria to assess the quality of the Informal Pro-active Approach Model. In: Dacian C. Dragos, François Lafarge and Paulien Willemsen (eds.), Proceedings of the EGPA Permanent Study Group: Law and Public Administration (33rd Annual Conference of the European Group for Public Administration, Bucharest, Romania 2011), Romania: Editura Economica, 126-143.

Marseille, A.T. (2016). Hoe de bezwaarprocedure bij de overheid kan profiteren van inzichten uit empirisch onderzoek. Justitiële Verkenningen 6, 79-94.

Marseille, A.T., B.W.N. de Waard and M. Wever. (2017). Evaluatie bezwaarschriftprocedure gemeente Tilburg. Groningen: Vakgroep Staatsrecht, Bestuursrecht en Bestuurskunde.

Meijer, H. and T. Latenstein van Voorst. (2017). Evaluatieonderzoek Horen in de bezwaarprocedure (Scriptie Bachelor Recht en Bestuur, Rijksuniversiteit Groningen), Groningen.

Ministerie van Binnenlandse zaken en Koninkrijksrelaties, Professioneel behandelen van bezwaarschriften, see: http://prettigcontactmetdeoverheid. $\mathrm{nl} /$ sites/default/Files/documenten/Handleiding\%20Professioneel\%20 behandelen\%20van\%20bezwaarschriften_0.pdf Handreiking.

Parliamentary Papers II, 1997/98, 25600 VI, nr. 46, p. 28. 
Polak, J.M. et.al. (1996). Toepassing en effecten van de Awb 1994-1996. Den Haag: Ministeries van Justitie en Binnenlandse Zaken.

Tyler, T.R. (1990). Why People Obey the Law. New Haven and London: Yale University Press.

Van den Bos, K., L. van der Velden and E.A. Lind (2014). On the Role of Perceived Procedural Justice in Citizens' Reactions to Government Decisions and the Handling of Conflicts. Utrecht Law Review 10(4), 1-26.

Van Montfort, J.G.M and G. Tromp (2000). Alleen tevreden met resultaat?. Beleidswetenschap, 340-358.

Wever, M. (2016). Bezwaarbehandeling door de overheid anno 2016. Vooral vernieuwing op papier?. NJB 2016/2289. 


\section{Nevtralnost in nizozemski postopek ugovora}

Na Nizozemskem je tistemu, ki se ne strinja z upravnim nalogom, pritožba pri upravnem sodišču dovoljena le potem, ko je vložil ugovor pri upravnem organu, ki je odgovoren za nalog. Postopek ugovora pomeni, da upravni organ ponovno preuči svojo odločitev. $V$ tem prispevku preučujemo naklonjenost vlagateljev ugovorov glede organizacije postopka in do katere mere je njihova naklonjenost povezana z zaznanim (pomanjkanjem) nevtralnosti osebe, ki je vodila zaslišanje. Še posebej se osredotočimo na učinke uporabe nevtralnih "zunanjih sodelavcev« med izvajanjem zaslišanj. Na podlagi literature smo domnevali, da bo uporaba zunanjih sodelavcev koristila zaznani nepristranskosti oseb(e), ki vodi zaslišanje. Toda rezultati dveh obravnavanih študij ne podpirajo te predpostavke. Uradni status oseb, ki vodijo zaslišanje, slabo napoveduje, v kolikšni meri jih bodo udeleženci postopka šteli za nevtralne.

Naš rezultat ni pokazal zaznavanja pomanjkanja nevtralnosti s strani javnih uslužbencev, ki so vodili zaslišanja. Študija v Groeningenu ni pokazala pomembnih razlik med vlagatelji ugovorov, ki jih je zaslišal zunanji odbor, in tistimi, ki so jih zaslišali javni uslužbenci, ki so delovali pod odgovornostjo upravnega organa, ki je sprejel sporno odločbo.

To ne zmanjšuje resničnosti dejstva, da bi večina vlagateljev ugovorov, če bi jim bila dana možnost, raje sodelovala z zunanjimi sodelavci. Študija, ki se je osredotočala na Tilburg, je pokazala, da bi kljub temu, da večina vlagateljev ugovorov ni občutila pomanjkanja nevtralnosti, velika večina raje sodelovala z zunanjim odborom za ugovore, saj verjamejo, da bi to pripeljalo do bolj nepristranskega in objektivnega pregleda izpodbijane odločbe. Kako naj to pojasnimo? Našli smo dve možni razlagi. Prva razlaga, ki smo jo našli, je, da so bili vlagatelji ugovorov, ki so izkusili nižjo stopnjo postopkovne pravice, bolj nagnjeni k alternativni možnosti (torej zunanjemu odboru). Druga razlaga je, da so vlagatelji ugovorov menili, da bi bila uporaba zunanjih sodelavcev na splošno bolj primerna glede na naravo samega postopka ugovora.

Posledice naših ugotovitev bi bile lahko pomembne za države, ki imajo podobno organizirane upravne predsodne postopke, kot je nizozemski postopek ugovora. Natančneje: uporaba zunanjih sodelavcev samodejno ne povzroči povečane izkušnje nepristranskosti. Status oseb, ki vodijo zaslišanja, je le eden od dejavnikov, ki vplivajo na oceno vlagateljev ugovorov glede kakovosti zaslišanja. Bolj kot njihov »uradni status« je pomemben dejanski način, na katerega oseba, ki vodi zaslišanje, opravi svojo nalogo. Status oseb, ki vodijo zaslišanja, postane pomembnejši za vlagatelje ugovorov, ko so le-ti 
nezadovoljni z načinom, na katerega je javni uslužbenec vodil zaslišanje, in še pomembnejši, če ima sam upravni organ pomemben interes glede določenega izida postopka ugovora. Za organe je priporočljivo, da te ugotovitve upoštevajo pri načrtovanju predsodnih postopkov.

Ključne besede: nevtralnost, postopki za reševanje sporov, upravni predobravnavni postopki, nizozemsko upravno pravo, procesna pravičnost. 